\title{
1 Embodied Energy and Cost of High 2 Temperature Thermal Energy Storage 3 Systems for use with Concentrated 4 Solar Power Plants
}

5 Rhys Jacob ${ }^{1 *}$, Martin Belusko $^{1}$, A. Inés Fernández ${ }^{2}$, Luisa F. Cabeza ${ }^{3}$, Wasim Saman ${ }^{1}$, Frank 6 Bruno $^{1}$

$7 \quad{ }^{1}$ Barbara Hardy Institute, University of South Australia, Mawson Lakes, SA 5095, Australia

$8{ }^{2}$ Department of Materials Science and Metallurgical Engineering, Universitat de Barcelona, Martí i Franqués 1, 908028 Barcelona, Spain

$10{ }^{3}$ GREA Innovació Concurrent, Universitat de Lleida, Edifici CREA, Pere de Cabrera s/n, 25001 Lleida, Spain

11 * Corresponding author E-mail: rhys.jacob@mymail.unisa.edu.au (R. Jacob)

\section{Abstract}

13 The intermittency of renewable energy systems remains one of the major hurdles preventing 14 a large scale uptake of these technologies and concentrated solar power (CSP) systems are no different. However, CSP has the benefit of being able to store excess heat using thermal energy storage (TES). For the uptake of CSP with TES it must be demonstrated that the technology is both economically as well as environmentally feasible. This paper aims to investigate the economic and environmental impact of several TES options that are available for CSP systems. The investigated systems include an encapsulated phase change material (PCM) system, a coil-in-tank PCM system and a liquid sodium TES system. The economic impact in the current study refers to the capital cost (CAPEX) of each system including the tank, storage material, encapsulation cost (if applicable) and allowances for construction and engineering. The environmental impact of each system is accounted by calculating the embodied energy of each of the system components. Each storage system will be required to store a comparable amount of energy so that reliable conclusions can be drawn. The results from this analysis conclude that the encapsulated PCM (EPCM) and coil-in-tank system represent an embodied energy of roughly one third of the corresponding state-of-the-art twotank molten salt system. 
Furthermore, the EPCM and coil-in-tank systems result in CAPEX reductions of $50 \%$ and $25 \%$ over the current state-of-the-art two-tank molten salt system. The liquid sodium system was found to result in higher embodied energy and CAPEX than any previously studied TES system. Finally, the advantages and disadvantages of each system was discussed and compared to previous literature.

Keywords: embodied energy; environmental impact; high temperature thermal energy storage (TES) systems; concentrated solar power (CSP) systems.

Abbreviations: Phase Change Material (PCM); Thermal Energy Storage (TES); Concentrated Solar Power (CSP); Capital Expenditure (CAPEX); Encapsulated Phase Change Material (EPCM).

38 1. Introduction

\section{$\underline{1.1 \quad \text { Background }}$}

The field of high temperature thermal energy storage (TES) has steadily been growing with several successful demonstrations showing the benefit of TES as a storage method for high temperature concentrated solar power (CSP), however the cost and environmental impacts of these system is largely unknown, unpublished or overlooked. Previous attempts at quantifying the embodied energy or carbon footprint of phase change material (PCM) TES have been performed by [Oró et al, 2012], [Anisur et al, 2013], [Lopez-Sabiron et al, 2014] and [Miró et al, 2015]. [Anisur et al, 2013] found that about 3.43\% of $\mathrm{CO}_{2}$ emissions by 2020 could be reduced through the application of PCM in building and solar thermal power systems. Further savings could be achieved if PCMs could be used in other applications such as thermal comfort of vehicles, transport refrigeration, engine cold start or waste heat management. [Lopez-Sabiron et al, 2014] investigated the potential of PCMs as a storage option for recovering waste heat for downstream applications, thereby reducing the amount of fossil fuel needed for heat generation. The life cycle analysis (LCA) and global warming potential (GWP100) methodology were used to identify the best cases, considering the environmental benefits that each case can generate. It was found that in general PCMs achieve an environmental benefit as the reduction in fossil fuel use is enough to balance the energy consumed in the production of the PCM. However, they noted that the selection of the PCM greatly influences the environmental benefit. This sentiment is echoed by [Miró et al, 2015] who investigated the embodied energy of three high temperature TES options. The studied options were high temperature concrete slabs, a two-tank molten salt system and a 
PCM system. From the analysis it was shown that the high temperature concrete system had the lowest embodied energy. As the liquid molten salt and PCM were nitrate-based the embodied energy of these systems was large. The results from [Miró et al, 2015] are found to be similar to that of previous research by [Oró et al, 2012] using the same methodology. [Oró et al, 2012] found that the solid TES system corresponded to the lowest LCA impact across all three of the main factors; namely eco system quality, human health and resources. The molten salt system was found to have the largest impact on human health and resources due to the materials used in the molten salt. The PCM studied by [Oró et al, 2012] was also found to have a high impact on human health and resources but was less than the molten salt system due to a lower material inventory. In the current study an environmental and economic analysis has been performed on several promising methods of high temperature TES. The embodied energy methodology has been selected as the environmental evaluation tool due to its versatility and ability to easily compare systems. This type of evaluation allows materials with large embodied energy values to be replaced by more favourable materials while still at the design phase, saving time and money. The embodied energy methodology can be defined as an energy accounting process investigating the energy used through the entire production chain. However, the main issue with this type of methodology is the lack of agreement on the system boundary: some of them consider the transport from the industry to the application, while others consider the disposal of the material or the percentage of recycled material in the production process. In the current study the embodied energy data has been taken from sources with known system boundaries so that a direct comparison can be made. The current method of storage for large scale CSP plants is the two-tank system utilising molten salt. While this method of storage has been successful in current plants, if CSP is to be economically competitive in the future the cost must be reduced. Furthermore, it has been shown that the two-tank molten salt storage method suffers from a significantly high environmental and health impact [Oro et al, 2012; Miró et al, 2015], reducing the environmental savings of the overall system. To achieve economical competiveness and a reduction in environmental impacts a new generation of CSP plants (and TES systems) must be realised. To increase the cost competiveness of future CSP plants they must be able to operate at higher temperatures to increase the turbine efficiency. The current operating limit of solar salt is $565^{\circ} \mathrm{C}$, which is well below the predicted temperature of $600^{\circ} \mathrm{C}-700^{\circ} \mathrm{C}$ required in future s- $\mathrm{CO}_{2}$ Brayton cycles. If storage is to be coupled to the new generation of turbines it must be able to supply heat above $600^{\circ} \mathrm{C}$. Furthermore, the cost of the storage 
system must be reduced to $\$ 25 / \mathrm{kWh}_{\mathrm{t}}$ in order to reduce the LCOE of the CSP plant to 12c/kWh [ASTRI, 2016]. Current two-tank molten salt storage systems are unable to achieve these targets so new methods of storage must be investigated. To this end PCMs or liquid metals are seen as a promising solution. PCMs are materials that can store/release a large amount of heat as they undergo a change of phase. The high energy density of these materials allows the storage volume and therefore the storage cost to be reduced. However, the main issue with current PCMs is their inherent low thermal conductivity. This low thermal conductivity leads to long charge/discharge times, which is undesirable for power generation. To increase the thermal conductivity, the PCM can either be encapsulated or placed in a coilin-tank arrangement. Alternatively, liquid metals, principally liquid sodium, have an inherently high thermal conductivity and high temperature stability which could allow them to be a suitable high temperature sensible energy storage option if the safety issues associated with them can be curtailed. To identify the potential benefits of PCM or liquid metal systems, an economic and environmental evaluation must be accomplished. Therefore, the aim of the current study is to quantify the environmental and economic impact of two (2) PCM-based and a liquid metal-based TES system. This will be done by utilising the embodied energy and CAPEX methodologies to identify if any or all of the proposed systems can reduce the environmental and economic impacts of the current two-tank molten salt system.

\section{TES Systems}

In the current study three different TES systems have been investigated due to their promising suitability with the next generation of CSP plants. Two of the systems utilise latent heat while the other is based on sensible heat storage. The investigated systems are:

- Encapsulated PCM (EPCM) system: latent heat system using a two chloride PCMs, geopolymer shell and air as the heat transfer fluid (HTF).

- Coil-in-Tank system: latent heat system with stainless steel tubes in which liquid sodium flows.

- Liquid sodium system: Two-tank sensible heat system using liquid sodium as the HTF and storage material.

\subsection{Encapsulated PCMs}

In an attempt to increase the PCM thermal conductivity it can be encapsulated in another material. 
124 As well as increasing the overall thermal conductivity of the material, encapsulation of PCMs also helps to form a barrier between the PCM and the containment material and helping to control the large volume change that occurs during phase change. A variety of PCMs and shell materials have been studied and demonstrated for high temperature applications [Mathur et al, 2013; Alam et al, 2015; Jacob and Bruno, 2015], however in the current study a novel solution proposed by [pending] has been selected for further study. The design and properties of the EPCM system are shown in Figure 1 and Table 1.

\section{INSERT FIGURE 1 HERE}

\section{INSERT TABLE 1 HERE}

\subsection{Coil-in-Tank PCMs}

134 In the coil-in-tank arrangement a HTF flows through tubes to exchange energy as heat to the bulk PCM (see Figure 2).

\section{INSERT FIGURE 2 HERE}

137 The amount and material of tubes is dependent on the corrosion capability and thermal 138 conductivity of the HTF and bulk PCM. In the current study the coil-in-tank system dimensions have been based on CFD analysis and the effectiveness-NTU method as presented in [Liu et al, 2014]. The parameters used to design the system can be found in Table 2.

\section{INSERT TABLE 2 HERE}

\subsection{Liquid Sodium Two-Tank}

145 As an alternative to molten salt receivers, liquid metals can be used due to their stability at

146 higher temperatures and increased thermal conductivity. Recent studies have shown the 147 benefit of using liquid metal receivers for future CSP plants [Pacio and Wetzel, 2013; 148 Coventry et al, 2015; Fritsch et al, 2015]. As the thermal conductivity of liquid metals is high 149 the solar field and receiver can be smaller therefore reducing cost. Additionally, the higher 150 operating temperatures that can be achieved allow high efficiency turbines to be used, further reducing the system cost. Of the liquid metals studied liquid sodium has been shown to be the most efficient and cost effective [Pacio and Wetzel, 2013] and despite potential safety concerns, proposals for liquid metal storage has been suggested [Fritsch et al, 2015]. In the 
current study the liquid sodium is stored in a 'hot' tank at $700^{\circ} \mathrm{C}$ and a 'cold' tank at $360^{\circ} \mathrm{C}$ as shown by Figure 3.

157 The design of the two-tank system was performed using the SAM software [NREL, 2015] where the properties of liquid sodium are taken from [Holman, 2010] and are listed in Table 3.

\section{INSERT TABLE 3 HERE}

$1613 . \quad$ Methodology

162 The specific methodology for the environmental and economic methodologies are given in 163 the following section.

\section{$164 \quad 3.1 \quad$ Environmental Evaluation}

165 The environmental evaluation used in the current study is based on embodied energy values

166 found on specialised software (such as EcoInvent [EcoInvent] and CES Selector [CES, 167 2012]) or published literature [Jamieson et al, 2015; McLellan et al, 2011]. Where indicated 168 the embodied energy has been taken directly from the data. Where this is not available an 169 educated assumption based on similar materials has been used. Multiple databases have been 170 used in the current study due to gaps in the data for this type of analysis. To minimise 171 discrepancies, the EcoInvent database was consulted first. If it could not be found there, CES 172 Selector or published literature values were used. Finally, educated estimates were used for 173 the remaining materials. In this analysis the embodied energy is used to describe the direct 174 energy input used to manufacture, transport and refine the material prior to construction. It 175 will not take into account any of the environmental externalities (eg. pollutants) unless 176 specifically mentioned. In addition, all systems are assumed to have equal lifetimes. At the 177 end of life materials are recycled where applicable.

\subsubsection{Embodied Energy Values}

179 Table 4 below shows the materials used in construction and their given embodied energy 180 value. 


\subsubsection{Tank Design}

184 The designs of the tanks used in the current study are based on previously reported designs 185 found in literature [Hermann et al, 2004; Kelly and Kearney, 2006]. As the temperature is 186 higher than previously installed tanks, a method of insulation thickness was developed, 187 wherein the insulation is based on a commercial high temperature mineral wool and $\mathrm{T}$ is the 188 stored temperature $\left({ }^{\circ} \mathrm{C}\right)$.

$$
\text { Insulation Thickness }(\mathrm{mm})=0.0018 T^{2}-0.8084 T+461.68
$$

190 The foundations of the tank consist of a steel slip ring, firebricks, foamglass insulation, a 191 concrete thermal foundation, and a reinforced concrete slab. For all cases the steel slip ring is 192 assumed to be $6 \mathrm{~mm}$ and constructed of stainless steel. The firebricks, foamglass insulation

193 and thermal foundation thickness is dependent on the temperature of the tank. The thickness 194 of the reinforced concrete is constant for each case. A summary of the tank design parameters are shown in INSERT TABLE 5 HERE

\section{INSERT TABLE 5 HERE}

197 An example of the tank design for the EPCM system is shown in Figure 6.

\section{INSERT FIGURE 5 HERE}

\subsection{Economic Evaluation}

200 The economic evaluation performed in the current study is based on a slightly modified costing methodology described in [Jacob et al, 2014] for the EPCM and coil-in-tank systems. The costing of the liquid sodium two-tank system was based on the cost of the storage material and tanks, subject to the same procedure. The cost data for the materials used in the current study are shown in Table 6. All costs are described in USD (\$) unless otherwise indicated.

\section{INSERT TABLE 6 HERE}

207 4. Results

208 In this section the environmental and economic results are compared for each design. Each 209 system has a desired storage capacity of $405 \mathrm{MWh}_{\mathrm{t}}$. The temperature of the sodium to and 210 from the power block is set to $700^{\circ} \mathrm{C}$ and $360^{\circ} \mathrm{C}$, respectively. For the air based system, the 
211 temperature of the air to and from the power block is set to $660^{\circ} \mathrm{C}$ and $360^{\circ} \mathrm{C}$, respectively.

212 Each system is assumed to operate independently from the receiver, with the parasitic losses

213 in the system assumed to be comparable in each system. As such as the storage capacity is the

214 same it can be assumed that the electricity generation will be the same. The effectiveness

215 described in each section is used to appropriately compare the systems. As not all of the

216 material is capable of $100 \%$ energy storage, an effectiveness can be used to 'oversize' the

217 system so that a desired storage capacity can be achieved.

\section{$218 \quad \underline{4} \quad$ Environmental Evaluation}

\section{$219 \quad$ 4.1.1 EPCM System}

220 The effectiveness of thermocline systems is generally 69\% [Brosseau et al, 2004], however it 221 is predicted to be more for cascaded PCM systems [Adebiyi et al, 1996; Wang et al, 2015].

222 Therefore, using the model described in [pending], a storage effectiveness and a storage capacity of $90 \%$ and $450 \mathrm{MWh}_{\mathrm{t}}$ respectively was calculated. The breakdown of the system embodied energy is shown in Figure 5.

\section{INSERT TABLE 7 HERE}

\section{INSERT FIGURE 6 HERE}

\subsubsection{Coil-in-Tank System}

228 The estimation of the size of the coil-in-tank system was performed using [Liu et al, 2014]. In this scenario the inlet $\mathrm{HTF}$ temperature was $700^{\circ} \mathrm{C}$, and an overall effectiveness of 0.9 is used ( 0.8 for latent, 0.6 for sensible). The embodied energy breakdown is shown in Figure 7.

\section{INSERT TABLE 8 HERE}

\section{INSERT FIGURE 7 HERE}

\subsubsection{Liquid Sodium System}

234 For the liquid sodium two-tank system, construction of the storage tank is assumed to be made from stainless steel. Usually for a two-tank system the 'cold' tank is made from carbon steel, however as sodium poses a major safety factor and corrosion rates of sodium on carbon steel are three times greater than for 316 stainless steel [Davis, 1997], both tanks will be constructed of stainless steel. An efficiency of $85 \%$ is used for the two-tank system owing to the liquid 'heel' left in each tank which is not utilised [Brosseau et al, 2004], therefore the 
system is designed for a storage capacity of 476MWht. The breakdown of embodied energy is shown in Figure 8.

\section{INSERT TABLE 9 HERE}

\section{INSERT FIGURE 8 HERE}

\subsubsection{Comparison and Energy Payback Period}

245 A comparison and breakdown of the embodied energy in the studied systems is shown in 246 Table 10.

As the goal of the thermal energy storage system (TESS) is to minimise the use of heavy polluting fossil fuels, the system should not require a significant amount of energy to construct compared to the additional output that the system can achieve. To calculate the energy payback of the TESS, the additional energy generated from the turbine is calculated assuming the storage is charged and discharged once a day (see Equation 2).

$$
Q_{\text {year }}=Q_{\text {cap }} * \eta_{\text {turbine }} * \text { Days }_{\text {op }}
$$

In Equation $2 \mathrm{Q}_{\text {cap }}, \eta_{\text {turbine }}$ and Days op have the values of $405 \mathrm{MWh}_{\mathrm{t}}, 37 \%$ and 355 days/year, respectively. Using these values, the TESS is able to supply an additional 192TJ of energy a year. The energy payback of each system is calculated and shown in Figure 10.

\section{INSERT FIGURE 9 HERE}

From Figure 10 it can be seen that the EPCM and coil-in-tank systems have the energy required in their construction offset in under two months. Due to the high embodied energy of the sodium two-tank system, the energy is not offset by the system until over three years has elapsed.

\subsection{Economic Evaluation}

263 Using the methodology previously discussed, the CAPEX of the studied systems could be estimated. The results from this analysis are shown in and Figure 9. 


\section{$\underline{5.1 \quad \text { Embodied Energy }}$}

269 The major contributor to the embodied energy of the EPCM and coil-in-tank systems (see

270 Figure 5 and Figure 7) is from the steel tank. For the two-tank sodium system, the sodium is the main contributor (see Figure 8). In all cases large amounts of embodied energy are from metals. This is due to the metal extraction and production process being highly energy intensive, with the energy used in this process largely derived from fossil fuels. To reduce the embodied energy of the storage tanks the steel can be replaced by a less energy intensive product such as concrete, such as those demonstrated by Airlight Energy [Airlight, 2016]. For example, the substitution of a steel tank to a concrete tank in the EPCM system results in a $41 \%$ reduction in embodied energy. Furthermore, the embodied energy of the tanks can be additionally reduced by substituting waste materials into the concrete mixture [McLellan et al, 2011; Jamieson et al, 2015]. Other methods to reduce the embodied energy of the studied systems include reducing or substituting the sodium silicate binder in the EPCM system, substituting the sodium HTF in the tubes with a less energy intensive HTF such as solar salt or air, or producing energy/electricity from renewable sources.

\subsection{CAPEX Estimate}

284 The cost breakdown for the studied systems can be seen in Figure 9. For the EPCM and coilin-tank systems the major contributors to the CAPEX are the encapsulation or tubing, the storage tank and the construction costs. In the liquid sodium case nearly half of the CAPEX is from the sodium storage material. Because of the low thermal conductivity of salt PCMs it should be encapsulated or in contact with a large amount of tubes/fins to reduce charging and discharging times. However, this increases the cost of the system by adding extra processing steps or extra materials. Cost reductions can be realised in the encapsulation process by the scale-up of the encapsulation process while the cost of tubing can be reduced by employing a thermally conductive PCM such as aluminium.

\section{$\underline{5.3}$ Comparison with previous work}

294 With no viable alternatives, the two-tank molten salt system was the only technology that could be used for large-scale TES in CSP until recently. With the successful pilot scale testing of concrete storage [Laing and Lehmann, 2008] and rock-bed thermocline systems with molten salt [Pacheco et al, 2002] there are now viable alternatives to the traditional twotank system. In addition, PCM systems (both coil-in-tank and EPCM) have been successfully 
demonstrated at small scale [Zanganeh et al, 2015]. As such there is now an increasing body

300 of work that investigates the non-operational aspects of these systems such as environmental 301 impact and system economics. The following section is used to discuss the findings in the current study with those published previously.

\subsubsection{Comparisons based on embodied energies}

304 As previously mentioned there has been little work to date investigating the embodied energy of high temperature TESS. However, several papers have been identified with the results summarised here and compared to the current study. [López-Sabirón et al, 2014] investigated the carbon footprint of TESS for recovery of industrial energy recovery as a method to reduce fossil fuel consumption. In this study a life cycle analysis (LCA) of four (4) PCM systems was carried out and evaluated using the Global Warming Potential (GWP) method. All systems were based on the same mass of PCM $(825 \mathrm{~kg})$ with a range of energy storage capabilities (see Figure 12).

313 Having sized the system, the carbon footprint could be found by including the PCM, HTF 314 (diphenylether-compounds) and the heat exchanger area (330kg of steel). Particular attention 315 was paid to the manufacture of the PCM, which has a significant impact on the final carbon 316 footprint of the system (see Figure 11).

\section{INSERT FIGURE 12 HERE}

In Figure 12 and Figure 11 the case number represents the potassium nitrate $\left(\mathrm{KNO}_{3}\right)$, sodium

319 hydroxide $(\mathrm{NaOH})$, carbonate $\left(\mathrm{K}_{2} \mathrm{CO}_{3} / \mathrm{Na}_{2} \mathrm{CO}_{3} / \mathrm{Li}_{2} \mathrm{CO}_{3}\right)$ and the lithium and potassium 320 hydroxide $(\mathrm{LiOH} / \mathrm{KOH})$ systems as described by [López-Sabirón et al, 2014].

321 [Miró et al, 2015] expanded on the previous work of [Oró et al, 2012] by analysing three (3) 322 high temperature TES options using the embodied energy of materials found in EcoInvent 323 [EcoInvent, 2016]. It was found that under the studied conditions the solid media system 324 utilising high temperature concrete blocks provided the lowest embodied energy with the 325 PCM system corresponding to the highest embodied energy. Molten salt two-tank systems 326 were found to the intermediate system (see Figure 13). 
Using the data contained in Figure 11 and Figure 13 a comparison of the embodied energy of the previously studied systems could be compared to the current work. Unfortunately due to the differing methodologies, inaccurate or unavailable data and assumptions used in the environmental analysis of high temperature TESS a direct comparison is difficult to make but is made here as an initial attempt (see Figure 14). In Figure 14 PCM-NO3, PCM-OH, PCM$\mathrm{CO} 3$ and PCM-OH2 correspond to cases 1-4, respectively, in [López-Sabirón et al, 2014], whereas PCM-NO3, SOLID-Concrete and 2-Tank-NO3 correspond to the PCM, solid and PCM systems described in [Miró et al, 2015].

\section{INSERT FIGURE 14 HERE}

337 From Figure 14 several conclusions can be made such as the importance of the evaluation method employed (carbon footprint vs embodied energy) and the type of PCM used. The varying environmental impact of high temperature PCMs was alluded to in [López-Sabirón et al, 2014] and confirmed in the current study. When nitrates are used as a storage material (either as sensible or latent) the environmental impact is significant and should be reconsidered. However, for less energy intensive materials such as chlorides, hydroxides and carbonates, the environmental impact is significantly less. For example, the embodied energy of halite $(\mathrm{NaCl})$ is $0.15 \mathrm{MJ} / \mathrm{kg}$ whereas the embodied energy of the nitrate salts $\left(\mathrm{K} / \mathrm{Na}-\mathrm{NO}_{3}\right)$ is over 100 times more at $16 \mathrm{MJ} / \mathrm{kg}$. This is also relevant when calculating the carbon footprint with sodium hydroxide $(\mathrm{NaOH})$ releasing nearly half as many kilograms of carbon-dioxide equivalent $\left(\mathrm{kg} \mathrm{CO} \mathrm{CO}_{2 \text {-eq }}\right)$ as $\mathrm{Li} / \mathrm{K}-\mathrm{OH}$ and $\mathrm{K} / \mathrm{Na} / \mathrm{Li}-\mathrm{CO}_{3}$ and nearly 14 times less than potassium nitrate [López-Sabirón et al, 2014]. More generally it can be seen that when the carbon footprint analysis is performed the results are much higher than those calculated using the embodied energy methodology. This is likely due to the different system boundaries and scope used in the analysis, the source of the input data or the conversion from carbon footprint to embodied energy ( $1 \mathrm{~kg} \mathrm{CO}_{2 \text {-e }}$ is equivalent to $7 \mathrm{MJ} / \mathrm{kg}$ in the current study). For more accurate comparisons to be made in the future a universal system boundary or methodology should be established. Furthermore, additional data on the embodied energy of materials used in high temperature TESS needs to be produced. This has successfully been prepared for building materials and other low temperature materials but needs to be expanded to the high temperature materials. In comparison with previous studies the EPCM and coil-intank systems described in the current study are able to achieve lower or comparable embodied energies with the other studied systems presented in the literature. It should be noted that the embodied energy of the EPCM and coil-in-tank system is roughly a third of the 
corresponding state-of-the-art two-tank molten salt system as presented in [Miró et al, 2015], therefore a major reduction in the environmental impact of these two (2) systems is realised with the energy payback estimated to be in the order of a couple of months. Due to the large embodied energy and energy payback of sodium it should not be recommended as an environmentally beneficial storage material in high temperature TESS.

\subsubsection{Comparison based on CAPEX estimations}

367 CAPEX estimations are an important part of project development as it is usually one of the major deciding factors as to whether a project is likely to be implemented or scaled up. If a project proves unfeasible at the planning stage it is highly unlikely to continue to be developed. CAPEX estimations of various alternatives to two-tank molten have begun to be published recently to showcase the cost benefits of such systems over the costly two-tank molten salt system. While difficult to directly compare CAPEX estimations as system boundaries and cost data may differ, the reported CAPEX of the studied systems are shown where possible.

\section{INSERT TABLE 13 HERE}

As most of the studies shown in Table 12 and Table 13 are for various system configurations it is difficult to quantitatively compare each system, however general conclusions can be made. Most CAPEX estimations are based on systems utilising EPCMs with solar salt as the HTF. It can be seen that there is quite a range of estimations for these systems $\left(\$ 5.7 / \mathrm{kWh}_{\mathrm{t}^{-}}\right.$ $\$ 22 / \mathrm{kWh}_{\mathrm{t}}$ ) with the major determining factor being the PCM used. It can also be seen that the HTF can have a major effect on the overall cost with oil-based systems suffering a significantly higher CAPEX $\left(\$ 108 / \mathrm{kWh}_{\mathrm{t}}\right)$ than solar salt $\left(\$ 13.9 / \mathrm{kWh}_{\mathrm{t}}\right)$ or air $\left(\$ 13.6 / \mathrm{kWh}_{\mathrm{t}}\right)$ based systems. Based on previous studies it would seem plausible that the EPCM system described in the current paper could achieve a lower CAPEX than those described in previous studies. The CAPEX of the coil-in-tank system seems to be in-line with other studied systems, however is still higher than other studied systems such as metallic alloy PCMs (Al$\left.\mathrm{Si}_{12}\right)$ or higher temperature carbonate PCMs $\left(51 \mathrm{~K}_{2} \mathrm{CO}_{3}: 49 \mathrm{NaCO}_{3}\right)$. The CAPEX of the coilin-tank could be reduced by optimising the system configuration or using cascaded PCMs to make it favourable with similar systems. However, it is also important to consider that the CAPEX for the EPCM and the coil-in-tank system described in the current study present savings of $50 \%$ and $25 \%$ respectively over the CAPEX of the two-tank system shown in 
393 [Glatzmaier, 2011]. The CAPEX of the liquid sodium system is significantly higher than any 394 studied high temperature TES system and should not be considered on economic grounds. 395 However due to the high thermal conductivity of liquid sodium system, it could potentially be 396 employed for small-scale ( $>3 \mathrm{hr}$ ) rapid response systems if managed correctly.

\section{6. Conclusions}

398 In the current study the embodied energy and CAPEX of three (3) high temperature TES options which have been proposed for CSP are estimated. The embodied energy of the studied systems was estimated using commercial software and relevant literature studies. Of the studied systems, the EPCM system resulted in the lowest value with an embodied energy equivalent to $47.8 \mathrm{TJ} / \mathrm{MWh}_{\mathrm{t}}$. The coil-in-tank had a similar embodied energy to the EPCM system $\left(65.2 \mathrm{TJ} / \mathrm{MWh}_{\mathrm{t}}\right)$ whereas the sodium two-tank system had a significantly larger embodied energy than the other studied cases $\left(1528 \mathrm{TJ} / \mathrm{MWh}_{\mathrm{t}}\right)$. The CAPEX of the system was estimated using the methodology described in [Jacob et al, 2014] with material costs found from various vendors. From these estimates the EPCM system resulted in the lowest CAPEX $(\$ 11.2 / \mathrm{kWht})$ followed by the coil-in-tank $\left(\$ 19.2 / \mathrm{kWh}_{\mathrm{t}}\right)$ and sodium two-tank $\left(\$ 43.4 / \mathrm{kWh}_{\mathrm{t}}\right)$ systems. Where possible the results found in the current study were compared to the embodied energy and CAPEX of other high temperature TES options with favourable results. It was concluded that the EPCM and coil-in-tank systems described in the current study have lower or comparable embodied energy values to other high temperature TES options. Furthermore, the current EPCM system resulted in a lower CAPEX than previous

413 EPCM systems. The current coil-in-tank system has a comparable CAPEX to similar systems 414 described in literature but would benefit from further optimisation including configuration 415 and the use of multiple PCMs. The two-tank liquid sodium tank was unable to result in a 416 lower embodied energy or CAPEX than the systems presented in the current study or those 417 presented in the literature.

\section{$\underline{6.1 \quad \text { Future Work }}$}

419 While the work presented in the current study provides an important advancement in the 420 environmental and economic impact of high temperature TES, there is still significant 421 improvements that can be made. Future work should be focussed on improving these types of study by: 
- Improving or increasing the transparency of the data obtained for embodied energy values.

- Implementing a well-defined system boundary for both the embodied energy and economic estimates.

By making these improvements a more thorough comparison between systems can be made. This will allow researchers and industry alike to focus on the technologies that are likely to provide a significant improvement on the currently employed two-tank molten salt TES system. Furthermore, a thorough investigation into the use of metallic PCMs (particularly aluminium) should be undertaken to determine if the higher material cost and embodied energy is offset by the higher energy density and reduced material usage.

\section{Acknowledgements}

This research was performed as part of the Australian Solar Thermal Research Initiative (ASTRI), a project supported by the Australian Government, through the Australian Renewable Energy Agency (ARENA). The work is partially funded by the Spanish government (ENE2015-64117-C5-1-R and ENE2015-64117-C5-2-R). The authors would like to thank the Catalan Government for the quality accreditation given to the research group GREA (2014 SGR 123) and DIOPMA (2014 SGR 1543). The research leading to these results has received funding from the European Union's Seventh Framework Programme (FP7/2007-2013) under grant agreement n PIRSES-GA-2013-610692 (INNOSTORAGE).

\section{References}

ASTRI (2016). About ASTRI. Available at: http://www.astri.org.au/. [Last Accessed $4^{\text {th }}$ March, 2016]

Adebiyi G.A, Hodge B.K, Steele W.G, Jaladeh A, Nso E.C. Computer simulation of a hightemperature thermal storage system employing multiple family of phase-change storage materials. J. Energy Resour. Technol. (1996); 118(2): 102-111.

Airlight Energy (2016). Concentrated Solar Power. Available at: http://www.airlightenergy.com/csp/. [Last Accessed $1^{\text {st }}$ March, 2016]

Alam T, Dhau J, Gosami D, Stefanakos E. Macroencapsulation and characterization of phase change materials for latent heat thermal energy storage systems. Applied Energy (2015); 154: 92-101. 
Bai F, Wang Y, Wang Z, Sun Y, Beath A. Economic Evaluation of Shell-and-Tube Latent

Heat Thermal Energy Storage for Concentrating Solar Power Applications. International (2014).

Brosseau D, Hlava P, Kelly M, (2004). Testing Thermocline Filler Materials and MoltenSalt Heat Transfer Fluids for Thermal Energy Storage Systems Used in Parabolic Trough Solar Power Plants. Sandia National Labratories, SAND2004-3207. Available at: http://www.nrel.gov/csp/troughnet/pdfs/brosseau_sand2004_3207_final.pdf

CES selector 2014 software, Granta Design Limited, Cambridge, UK; (2012):

465 www.grantadesign.com

466 Coventry J, Andraka C, Pye J, Blanco M, Fisher J. A review of sodium receiver technologies 467 for central receiver solar power plants. Solar Energy (2015); 122: 749-762.

468 Davis J.R, (1997). ASM Specialty Handbook: Heat-Resistant Materials. ASM International: 469 p.176; ISBN: 978-0-87170-596-9.

470 The Ecoinvent Centre. A competence centre of ETH; PSI; Empa \& ART.

471 Ecoinvent data v2.1: $\underline{\text { http://www.ecoinvent.ch/ }}$

472 Fritsch A, Flesch J, Geza V, Singer Cs, Uhlig R, Hoffschmidt B. Conceptual study of central 473 receiver systems with liquid metals as efficient heat transfer fluids. Energy Procedia (2015); 474 69: $644-653$.

475 Glatzmaier G, (2011). Developing a cost model and methodology to estimate capital costs for 476 thermal energy storage. National Renewable Energy Laboratory, NREL/TP-550053066, pp. 477 1-17. 
478 Herrmann U, Kelly B, Price H. Two-tank molten salt storage for parabolic trough solar 479 power plants. Energy (2004); 29; 883-893.

480 Holman J.P, (2010). Heat Transfer. 10 ${ }^{\text {th }}$ Edition. New York, McGraw Hill.

481 Jacob R, Saman W, Belusko M, Bruno F (2014). Techno-Economic Analysis of Phase 482 Change Material Thermal Energy Storage Systems in High Temperature Concentrated Solar 483 Power Plants. Asia-Pacific Solar Research Conference: http://apvi.org.au/solar-research484 conference/wp-content/uploads/2015/04/6-R-Jacob_peer_reviewed.pdf.

485 Jacob R, Bruno F. Review on shell materials used in the encapsulation of phase change 486 materials for high temperature thermal energy storage. Renewable and Sustainable Energy 487 Reviews (2015); 48: 79-87.

488 Jamieson E, McLellan B, Van Rissen A, Nikraz H. Comparison of embodied energies of 489 Ordinary Portland Cement with Bayer-derived geopolymer products. Journal of Cleaner 490 Production (2015); 99: 112-118.

491 Kelly B, Kearney D, (2006). Thermal storage commercial plant design for a 2-tank indirect 492 molten salt system. National Renewable Energy Laboratory, NREL/SR-550040166, pp. 1-32.

Laing D, Lehmann D. Concrete Storage for Solar Thermal Power Plants and Industrial 494 Process Heat. IRES III, Berlin (2008).

495 Liu M, NHS Tay, Bell S, Belusko M, Jacob R, Will G, Saman W, Bruno F. Review on 496 concentrating solar power plants and new developments in high temperature thermal energy 497 storage technologies. Renewable and Sustainable Energy Reviews (2016); 53: 1411-1432.

498 Liu M, Tay N.H.S, Belusko M, Bruno F. Investigation of cascaded shell and tube latent heat 499 storage systems for solar tower power plant. International Conference on Concentrating Solar 500 Power and Chemical Energy Systems, SolarPACES (2014). 
501 Lopez-Sabiron A, Royo P, Ferreira V, Aranda-Uson A, Ferreira G. Carbon footprint of a 502 thermal energy storage system using phase change materials for industrial energy recovery 503 to reduce the fossil fuel consumption. Applied Energy (2014); 135: 616-624.

504 Mathur A, Kasetty R, Oxley J, Mendez J, Nithyanandam K. Using encapsulated phase 505 change salts for concentrated solar power plant. International Conference on Concentrating 506 Solar Power and Chemical Energy Systems, SolarPACES (2013).

507 Marianowski LG, Maru HC (1977). Latent heat thermal energy storage systems above $508450^{\circ} \mathrm{C}$. In: Proceedings of 12 th Intersociety Energy Conversion Engineering Conference, p. $509 \quad 555-566$.

510 Maru HC, Dullea JF, Kardas A, Paul L, Marianowski LG, Ong E, Sampath V, Huang V, 511 Wolak J, (1978). Molten salts energy storage systems. Chicago, IL: Final Report of the 512 Institute of Gas Technology.

513 Mathur A, Kasetty R, Oxley J, Mendez J, Nithyanandam K. Using encapsulated phase 514 change salts for concentrated solar power plant. International Conference on Concentrating 515 Solar Power and Chemical Energy Systems, SolarPACES (2013).

516 McLellan B, Williams R, Lay J, van Riessen A, Corder G. Costs and carbon emissions of 517 geopolymer pastes in comparison to ordinary Portland cement. Journal of Cleaner 518 Production (2011); 19(9-10); 1080-1090.

519 Miró L, Oró E, Boer D, Cabeza L.F. Embodied energy in thermal energy storage (TES) 520 systems for high temperature applications. Applied Energy (2015); 137: 793-799.

521 Nithyanandam K, Pitchumani R. Optimization of an encapsulated phase change material 522 thermal energy storage system. Solar Energy (2014); 107: 770-788.

523 NREL, (2015). SAM Software. Available at: https://sam.nrel.gov/download

524 Oró E, Gil A, de Gracia A, Boer D, Cabeza L.F. Comparative life cycle assessment of 525 thermal energy storage systems for solar power plants. Renewable Energy (2012); 44: 166526173. 
527 Pacheco J, Showalter S, Kolb W. Development of a Molten-Salt Thermocline Thermal

528 Storage System for Parabolic Trough Plants. Journal of Solar Energy Engineering (2002);

529 124: 153-159.

530 Pacio J, Wetzel Th. Assessment of liquid metal technology status and research paths for their

531 use as efficient heat transfer fluids in solar central receiver systems. Solar Energy (2013); 93:

$532 \quad 11-22$.

533 Wang P, Wang X, Huang Y, Li C, Peng Z, Ding Y. Thermal energy charging behaviour of a

534 heat exchange device with a zigzag plate configuration containing multi-phase-change

535 materials (m-PCMs). Applied Energy (2015); 142: 328-336.

$536 \mathrm{Xu}$ B, Li P, Chan C, Tumilowicz E. General volume sizing strategy for thermal storage

537 system using phase change material for concentrated solar thermal power plant. Applied

538 Energy (2015): 140; 256-268.

$539 \mathrm{Xu} \mathrm{B,} \mathrm{Li} \mathrm{P,} \mathrm{Chan} \mathrm{C.} \mathrm{Application} \mathrm{of} \mathrm{phase} \mathrm{change} \mathrm{materials} \mathrm{for} \mathrm{thermal} \mathrm{energy} \mathrm{storage} \mathrm{in}$

540 concentrated solar thermal power plants: A review to recent developments. Applied Energy

541 (2015a); 160: 286-307.

542 Zanganeh G, Khanna R, Walser C, Pedretti A, Haselbacher A, Steinfeld A. Experimental and 543 numerical investigation of combined sensible-latent heat for thermal energy storage at $544 \quad 575^{\circ} \mathrm{C}$ and above. Solar Energy (2015); 114: 77-90.

545 TABLES

\begin{tabular}{|c|c|c|c|c|}
\hline & PCM1 & PCM2 & Shell & HTF \\
\hline Description & $\begin{array}{l}\text { 53BaCl:28KCl:19NaCl } \\
(w t \%) \quad[M a r i a n o w s k i \\
\text { and Maru, 1977] [Maru } \\
\text { et al, 1978] }\end{array}$ & $\begin{array}{l}36 \mathrm{KCl}: 64 \mathrm{MgCl}_{2} \\
(\mathrm{wt} \%) \quad[\text { Marianowski } \\
\text { and Maru, 1977] } \\
\text { [Maru et al, 1978] }\end{array}$ & $\begin{array}{l}\text { Fly Ash/Black Slag } \\
\text { Geopolymer }\end{array}$ & $\begin{array}{l}\text { Air [Holman, } \\
\text { 2010] }\end{array}$ \\
\hline$\rho\left(\mathrm{kg} / \mathrm{m}^{3}\right)$ & $\begin{array}{l}3010(\mathrm{~s}) \\
2342(1)\end{array}$ & $\begin{array}{l}2190(\mathrm{~s}) \\
1752(\mathrm{l})\end{array}$ & 2500 & 0.39 \\
\hline cp (kJ/kgK) & 0.63 & 0.84 & 0.6 & 1.12 \\
\hline$\Delta \mathrm{h}(\mathrm{kJ} / \mathrm{kg})$ & 221 & 388 & - & - \\
\hline
\end{tabular}




\begin{tabular}{|c|l|l|l|}
\hline & PCM & Tubing & HTF \\
\hline Description & $\begin{array}{l}40 \mathrm{NaCl}: 60 \mathrm{NaCO}_{3} \\
(\mathrm{wt} \%)[?]\end{array}$ & Stainless Steel 316 & $\begin{array}{l}\text { Sodium [Holman, } \\
2010]\end{array}$ \\
\hline $\boldsymbol{\rho}\left(\mathbf{k g} / \mathbf{m}^{3}\right)$ & $2300(\mathrm{~s})$ & 7900 & 830 \\
\hline $\mathbf{c p}(\mathbf{k J} / \mathbf{k g K})$ & 0.98 & 0.5 & 1.26 \\
\hline $\boldsymbol{\Delta h}(\mathbf{k J} / \mathbf{k g})$ & 278 & - & - \\
\hline
\end{tabular}

Table 2- Coil-in-tank System Parameters

\begin{tabular}{|l|l|l|l|l|l|}
\hline $\begin{array}{l}\text { Temperature } \\
\left({ }^{\circ} \mathbf{C}\right)\end{array}$ & $\begin{array}{l}\text { Heat Capacity } \\
\left(\mathbf{k J} / \mathbf{k g}^{\circ} \mathbf{C}\right)\end{array}$ & Density $\left(\mathbf{k g} / \mathbf{m}^{\mathbf{3}}\right)$ & Viscosity (Pa.s) & $\begin{array}{l}\text { Kinematic } \\
\text { Viscosity }\left(\mathbf{m}^{2} / \mathbf{s}\right)\end{array}$ & $\begin{array}{l}\text { Thermal } \\
\text { Conductivity } \\
\left(\mathbf{W} / \mathbf{m}^{\circ} \mathbf{C}\right)\end{array}$ \\
\hline 204 & 1.34 & 900 & $4.3 \mathrm{E}-04$ & $4.78 \mathrm{E}-07$ & 80.3 \\
\hline $304^{*}$ & 1.32 & 876 & $3.8 \mathrm{E}-04$ & $4.29 \mathrm{E}-07$ & 76.2 \\
\hline $404^{*}$ & 1.31 & 852 & $3.3 \mathrm{E}-04$ & $3.79 \mathrm{E}-07$ & 72.1 \\
\hline $504^{*}$ & 1.29 & 828 & $2.8 \mathrm{E}-04$ & $3.30 \mathrm{E}-07$ & 67.9 \\
\hline $604^{*}$ & 1.28 & 804 & $2.3 \mathrm{E}-04$ & $2.80 \mathrm{E}-07$ & 63.8 \\
\hline 704 & 1.26 & 780 & $1.8 \mathrm{E}-04$ & $2.31 \mathrm{E}-07$ & 59.7 \\
\hline
\end{tabular}

*Interpolated Values

Table 3- Liquid Sodium Properties

551

\begin{tabular}{|c|c|c|c|}
\hline Material & Embodied Energy (MJ/kg) & Description & Reference \\
\hline Sodium & 136.5 & Sodium & CES \\
\hline Stainless Steel (Plate) & 80.6 & $\begin{array}{l}\text { Stainless Steel, austenitic, } \\
\text { AISI 316, wrought, annealed, } \\
\text { recycled }\end{array}$ & CES \\
\hline Concrete (Foundation) & 0.35 & $\begin{array}{l}\text { Concrete (normal(Portland } \\
\text { Cement)), recycled }\end{array}$ & CES \\
\hline $\begin{array}{l}\text { Concrete } \\
\text { Temperature) }\end{array}$ & 0.35 & $\begin{array}{l}\text { Concrete (high alumina), } \\
\text { recycled }\end{array}$ & CES \\
\hline $\mathrm{NaCl}$ & 0.15 & Halite $(\mathrm{NaCl})$ & CES \\
\hline Tubes of Steel & 4 & $\begin{array}{l}\text { Drawing of pipes, steel [kg] } \\
(\# 1163)\end{array}$ & EcoInvent \\
\hline Rock Wool & 22 & $\begin{array}{l}\text { Rock wool, packed, at plant } \\
{[\mathrm{kg}](\# 1001)}\end{array}$ & EcoInvent \\
\hline Foamglass & 36 & $\begin{array}{l}\text { Foam glass, at plant }[\mathrm{kg}] \\
(\# 7160)\end{array}$ & EcoInvent \\
\hline
\end{tabular}




\begin{tabular}{|l|l|l|l|}
\hline Firebricks & 20 & $\begin{array}{l}\text { Refractory, fireclay, packed, } \\
\text { at plant [kg] (\#498) }\end{array}$ & EcoInvent \\
\hline Fly Ash & 0.05 & Capture, Separation & McLellan et al. 2011 \\
\hline Black Slag & 0.05 & Assumed same as Fly Ash & - \\
\hline Sodium Silicate Solution & 0.87 & GPC is $80 \%$ OPC, unrecycled & Jamieson et al 2015, CES \\
\hline Air & 0 & - & - \\
\hline $\mathrm{BaCl}$ & $0.21^{*}$ & Calculated Value & CES \\
\hline $\mathrm{KCl}$ & $0.21^{*}$ & Calculated Value & CES \\
\hline $\mathrm{MgCl}_{2}$ & $0.2^{*}$ & Calculated Value & CES \\
\hline $\mathrm{NaCO}_{3}$ & $0.2^{*}$ & Calculated Value & CES \\
\hline
\end{tabular}

*When embodied energy is graphed against price an approximately linear relationship is found. Using the bulk price of materials the embodied energy of similar materials can be found (see Figure 4).

\begin{tabular}{|c|c|c|c|c|c|c|c|}
\hline Material & \multicolumn{3}{|c|}{ Density $\left(\mathrm{kg} / \mathrm{m}^{3}\right)$} & \multicolumn{4}{|c|}{ Thickness (mm) } \\
\hline Mineral Wool & $\begin{array}{l}48 \\
{\left[350^{\circ} \mathrm{C}\right]}\end{array}$ & $\begin{array}{l}64 \\
{\left[450^{\circ} \mathrm{C}\right]}\end{array}$ & $\begin{array}{l}80 \\
{\left[650^{\circ} \mathrm{C}\right]}\end{array}$ & $\begin{array}{l}403 \\
{\left[360^{\circ} \mathrm{C}\right]}\end{array}$ & $\begin{array}{l}72 \\
{[66}\end{array}$ & & $\begin{array}{l}789 \\
{\left[700^{\circ} \mathrm{C}\right]}\end{array}$ \\
\hline Steel Ring & \multicolumn{3}{|l|}{7900} & \multicolumn{4}{|l|}{6} \\
\hline Firebricks & \multicolumn{3}{|l|}{1915} & \multicolumn{2}{|c|}{$0\left[\leq 360^{\circ} \mathrm{C}\right]$} & \multicolumn{2}{|c|}{$165\left[>360^{\circ} \mathrm{C}\right]$} \\
\hline Foamglass & \multicolumn{3}{|l|}{120} & \multicolumn{2}{|c|}{$400\left[\leq 360^{\circ} \mathrm{C}\right]$} & \multicolumn{2}{|c|}{$300\left[>360^{\circ} \mathrm{C}\right]$} \\
\hline Thermal Foundation & \multicolumn{3}{|l|}{2400} & \multicolumn{2}{|c|}{$0\left[\leq 360^{\circ} \mathrm{C}\right]$} & \multicolumn{2}{|c|}{$230\left[>360^{\circ} \mathrm{C}\right]$} \\
\hline Reinforced Concrete* & \multicolumn{3}{|l|}{2400} & \multicolumn{4}{|l|}{610} \\
\hline
\end{tabular}

* Steel reinforcement is required at a ratio of $73 \mathrm{~kg} \mathrm{steel} / \mathrm{m}^{3}$ concrete

\begin{tabular}{|l|c|c|c|}
\hline & EPCM System & Coil-in-Tank System & Liquid Sodium 2-Tank \\
\hline$C_{F M}(\$ / \mathrm{kg})$ & $0.33(\mathrm{PCM} 1)$ & $0.19[\mathrm{Xu}$ et al, 2015a; & 2 [Pacio and Wetzel, \\
& $\begin{array}{r}0.26(\mathrm{PCM} 2) \\
{[\mathrm{Xu} \text { et al, 2015a; }} \\
\end{array}$ & Liu et al, 2015] & $2013]$ \\
& Liu et al, 2015] & & \\
\hline$C_{S H E L L}(\$ / \mathrm{kg})$ & $0.05[p e n d i n g]$ & N/A & N/A \\
\hline$C_{H T F}(\$ / \mathrm{kg})$ & 0 & $2[$ Pacio and Wetzel, & N/A \\
& & $2013]$ & N/A \\
\hline$C_{T U B E}(\$ / \mathrm{kg})$ & N/A & $3.4[p e n d i n g]$ & \\
\hline
\end{tabular}




\begin{tabular}{|c|c|c|c|c|}
\hline & Material & $\begin{array}{l}\text { Estimated Usage } \\
(\mathrm{kg})\end{array}$ & $\begin{array}{l}\text { Embodied Energy } \\
(\mathrm{MJ} / \mathrm{kg})\end{array}$ & $\begin{array}{l}\text { Total Embodied } \\
\text { Energy }(\mathbf{M J})\end{array}$ \\
\hline \multirow[t]{8}{*}{ Tank } & Stainless Steel Tank & 98,949 & 80.6 & $7,975,284$ \\
\hline & Tank Insulation & 28,495 & 22 & 626,901 \\
\hline & Steel Slip Ring & 23,242 & 80.6 & $1,873,268$ \\
\hline & Firebricks & 154,931 & 20 & $3,098,626$ \\
\hline & Foamglass Insulation & 17,652 & 36 & 635,465 \\
\hline & Thermal Foundation & 270,661 & 0.35 & 94,731 \\
\hline & Concrete Foundation & 717,840 & 0.35 & 251,244 \\
\hline & Steel Reinforcements & 21,834 & 4 & $2,871,359$ \\
\hline \multirow{3}{*}{$\begin{array}{l}\text { Storage } \\
\text { Material }\end{array}$} & (Ba-K-Na)-Cl & 105,673 & 0.2 & 21,115 \\
\hline & $(\mathrm{K}-\mathrm{Mg})-\mathrm{Cl}_{(2)}$ & $2,007,786$ & 0.2 & 398,696 \\
\hline & Air & 613 & - & - \\
\hline \multirow[t]{2}{*}{ Encapsulation } & Geopolymer & $1,628,422$ & 0.05 & 14,981 \\
\hline & Binder & 705,650 & 0.87 & $1,483,167$ \\
\hline
\end{tabular}

Table 7-Material Usage and Embodied Energy in EPCM System

\begin{tabular}{|c|c|c|c|c|}
\hline & Material & $\begin{array}{l}\text { Estimated Usage } \\
(\mathrm{kg})\end{array}$ & $\begin{array}{l}\text { Embodied } \text { Energy } \\
(\mathrm{MJ} / \mathrm{kg})\end{array}$ & $\begin{array}{l}\text { Total Embodied } \\
\text { Energy }(\mathrm{MJ})\end{array}$ \\
\hline \multirow[t]{8}{*}{ Tank } & Stainless Steel Tank & 194,912 & 80.6 & 827,828 \\
\hline & Tank Insulation & 37,629 & 22 & 566,470 \\
\hline & Steel Slip Ring & 7,028 & 80.6 & 937,014 \\
\hline & Firebricks & 46,851 & 20 & 192,162 \\
\hline & Foamglass Insulation & 5,338 & 36 & 28,646 \\
\hline & Thermal Foundation & 81,847 & 0.35 & 75,975 \\
\hline & Concrete Foundation & 217,072 & 0.35 & 868,289 \\
\hline & Steel Reinforcements & 6,603 & 4 & $3,260,889$ \\
\hline \multirow{2}{*}{$\begin{array}{l}\text { Storage } \\
\text { Material }\end{array}$} & $\mathrm{NaCO}_{3}-\mathrm{NaCl}$ & $4,812,426$ & 0.18 & 861,251 \\
\hline & HTF & 22,481 & 136.5 & $3,068,700$ \\
\hline Tubing & Stainless Steel & 815,222 & 4 & $3,260,889$ \\
\hline
\end{tabular}

Table 8- Material Usage and Embodied Energy in Coil-in-tank System 


\begin{tabular}{|l|l|l|l|l|}
\hline \multirow{4}{*}{ Tank } & Material & $\begin{array}{l}\text { Estimated Usage } \\
(\mathbf{k g})\end{array}$ & $\begin{array}{l}\text { Embodied } \\
\text { Energy } \\
\mathbf{( M J} / \mathbf{k g})\end{array}$ & $\begin{array}{l}\text { Total Embodied Energy } \\
\mathbf{( M J )}\end{array}$ \\
\cline { 2 - 5 } & Stainless Steel Tank & 768,988 & 80.6 & $61,980,412$ \\
\cline { 2 - 5 } & Tank Insulation & 82,878 & 22 & $1,823,306$ \\
\cline { 2 - 5 } & Steel Slip Ring & 25,545 & 80.6 & $2,058,948$ \\
\cline { 2 - 5 } & Firebricks & 85,144 & 20 & $1,702,883$ \\
\cline { 2 - 5 } & Foamglass Insulation & 22,635 & 36 & 814,862 \\
\cline { 2 - 5 } & Thermal Foundation & 148,745 & 0.35 & 52,061 \\
\cline { 2 - 5 } & Concrete Foundation & 788,993 & 0.35 & 276,148 \\
\cline { 2 - 5 } & Steel Reinforcements & 23,999 & 4 & $3,155,972$ \\
\hline Storage Material & Sodium & $4,007,962$ & 136.5 & $547,086,879$ \\
\hline
\end{tabular}

\begin{tabular}{|c|c|c|c|}
\hline & EPCM & Coil-in-Tank & Liquid Sodium Two-Tank \\
\hline Steel (Tank) (MJ) & $12,719,911$ & $17,144,645$ & $67,195,332$ \\
\hline Concrete $(M J)$ & 345,975 & 104,622 & 328,208 \\
\hline Insulation/Firebricks (MJ) & $4,360,991$ & $1,957,005$ & $4,341,050$ \\
\hline HTF (MJ) & - & $3,068,700$ & $547,086,879$ \\
\hline$P C M(M J)$ & 419,811 & 861,251 & - \\
\hline Shell/Tubing (MJ) & $1,498,148$ & $3,260,889$ & - \\
\hline Total (MJ) & $19,344,836$ & $26,397,112$ & $618,951,470$ \\
\hline Total $\left(M J / M W h_{t h}\right)$ & 47,765 & 65,178 & $1,528,275$ \\
\hline
\end{tabular}

567

\begin{tabular}{|l|c|c|c|}
\hline & EPCM & Coil-in-Tank & $\begin{array}{l}\text { Liquid } \\
\text { Sodium }\end{array}$ \\
\hline Cost of Encapsulation/Tubing (\$) & $992,111.77$ & $2,771,755.88$ & - \\
\hline Cost of Storage Tank(s) (\$) & $1,044,949.90$ & $1,063,794.57$ & $3,058,098.34$ \\
\hline Cost of Storage Material (\$) & $556,896.47$ & $895,111.20$ & $8,015,924.97$ \\
\hline Balance of System Cost (\$) & $357,207.21$ & $357,207.21$ & $420,243.77$ \\
\hline Construction Cost (\$) & $885,349.60$ & $1,526,360.66$ & $3,448,280.13$ \\
\hline Engineering and Inspection Cost (\$) & $383,651.49$ & $661,422.95$ & $1,494,254.72$ \\
\hline Contingency Cost (\$) & $295,411.65$ & $509,295.67$ & $1,150,576.14$ \\
\hline Installed Cost (\$) & $4,515,578.09$ & $7,784,948.15$ & $17,587,378.07$ \\
\hline Installed Cost (\$/kWh $\mathbf{t})$ & $\underline{11.15}$ & $\underline{19.22}$ & $\underline{43.43}$ \\
\hline
\end{tabular}




\begin{tabular}{|c|c|c|c|}
\hline Storage Description & $\begin{array}{l}\text { CAPEX Estimate } \\
(\$ / \mathbf{k W h})\end{array}$ & Ref & Notes \\
\hline 3-PCM EPCM System & 16 & [Mathur et al, 2013] & $\begin{array}{l}\text { Developed product trading } \\
\text { under Terrafore }(\subset)\end{array}$ \\
\hline Cascaded EPCM System & $\begin{array}{l}5.8[1 \mathrm{PCM}] \\
5.7[2-\mathrm{PCM}] \\
5.8[3-\mathrm{PCM}]\end{array}$ & $\begin{array}{l}\text { [Nithyanandam and } \\
\text { Pitchumani, 2014] }\end{array}$ & \\
\hline EPCM System & $\begin{array}{l}109[\mathrm{PCM} 1,8 \mathrm{~h}] \\
115[\mathrm{PCM} 1,6 \mathrm{~h}] \\
101[\mathrm{PCM} 2,6 \mathrm{~h}]\end{array}$ & [Xu et al, 2015] & $\begin{array}{l}\text { Therminol VP-1 used as } \\
\text { HTF; likely cause of high } \\
\text { costs }\end{array}$ \\
\hline EPCM System & $\begin{array}{l}21[\mathrm{PCM} 1,8 \mathrm{~h}] \\
22[\mathrm{PCM} 1,6 \mathrm{~h}] \\
21[\mathrm{PCM} 2,6 \mathrm{~h}]\end{array}$ & [Xu et al, 2015a] & Solar Salt used as HTF \\
\hline EPCM System & 15.9 & [Jacob et al, 2014] & $\begin{array}{l}\text { Alloy PCM, Silicon Carbide } \\
\text { Shell }\end{array}$ \\
\hline Cascaded EPCM System & 11.2 & Current Study & $\begin{array}{l}\text { Geopolymer Shell, } \\
\text { 53BaCl:28KCl:19NaCl } \\
\text { PCM, Air HTF }\end{array}$ \\
\hline
\end{tabular}

\begin{tabular}{|c|c|c|c|}
\hline Storage Description & CAPEX Estimate $(\$ / \mathbf{k W h})$ & Ref & Notes \\
\hline $\begin{array}{l}\text { Shell-and-tube Latent } \\
\text { Heat System }\end{array}$ & $\begin{array}{l}9.5 \text { [PCM-1, Tower }] \\
21.6[\text { PCM-2, Tower }] \\
17.7[\text { PCM-1, Trough }]\end{array}$ & [Bai et al, 2014] & $\begin{array}{l}\text { Lowest cost of system } \\
\text { shown }\end{array}$ \\
\hline Coil-in-tank PCM System & $\begin{array}{l}\text { 19.7 [450 PCM, Incalloy Tubes] } \\
19.1 \text { [623 PCM, Incalloy Tubes] } \\
22.8 \text { [508 PCM, SS316 Tubes] } \\
48.3 \text { [560 PCM, Incalloy Tubes] } \\
12.1 \quad \text { [Al-Si PCM, Titanium } \\
\text { Tubes] } \\
10.2 \text { [710 PCM, SS316 Tubes] }\end{array}$ & $\begin{array}{l}{\left[\begin{array}{l}\text { Jacob et al, } \\
2014]\end{array}\right.} \\
\end{array}$ & $\begin{array}{l}\text { Variety of PCMs and tube } \\
\text { materials studied }\end{array}$ \\
\hline Coil-in-tank PCM System & 19.2 [623 PCM, SS 316 Tubes] & Current Study & \\
\hline
\end{tabular}




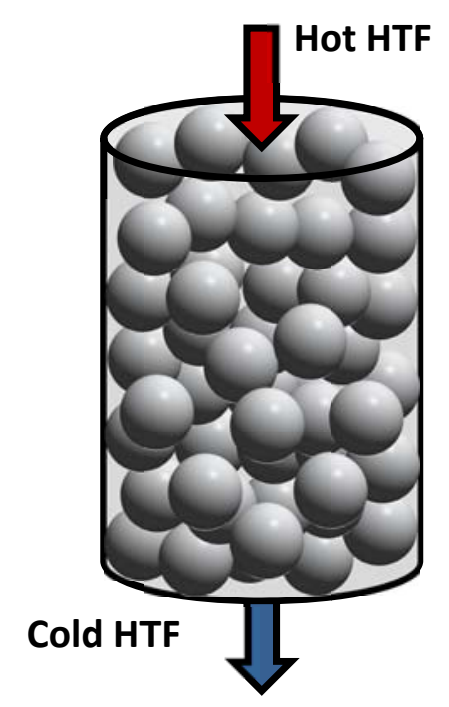

Figure 1- EPCM System

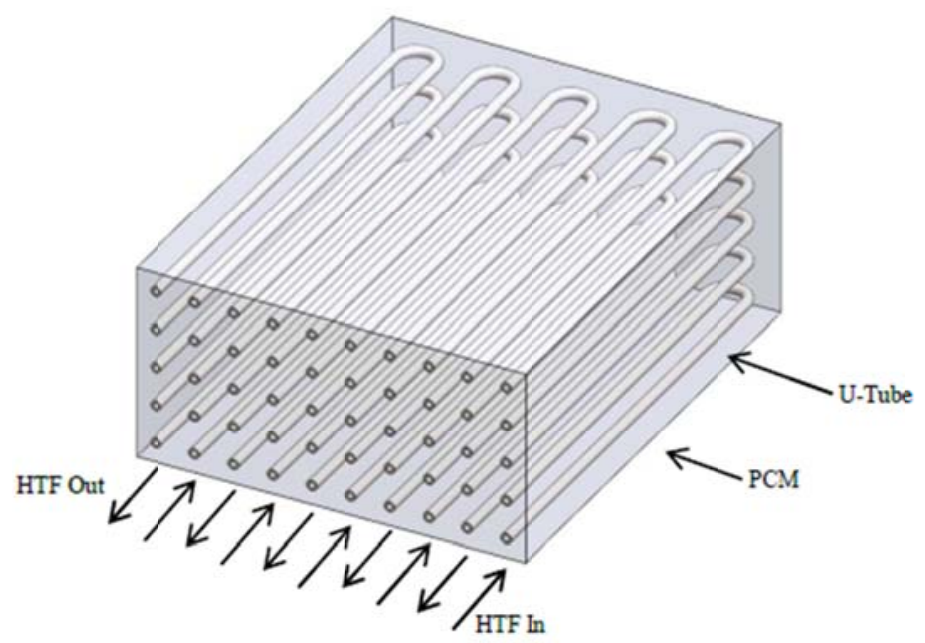

Figure 2- Tube-in-tank (shell and tube) PCM energy storage system with U-Tube 

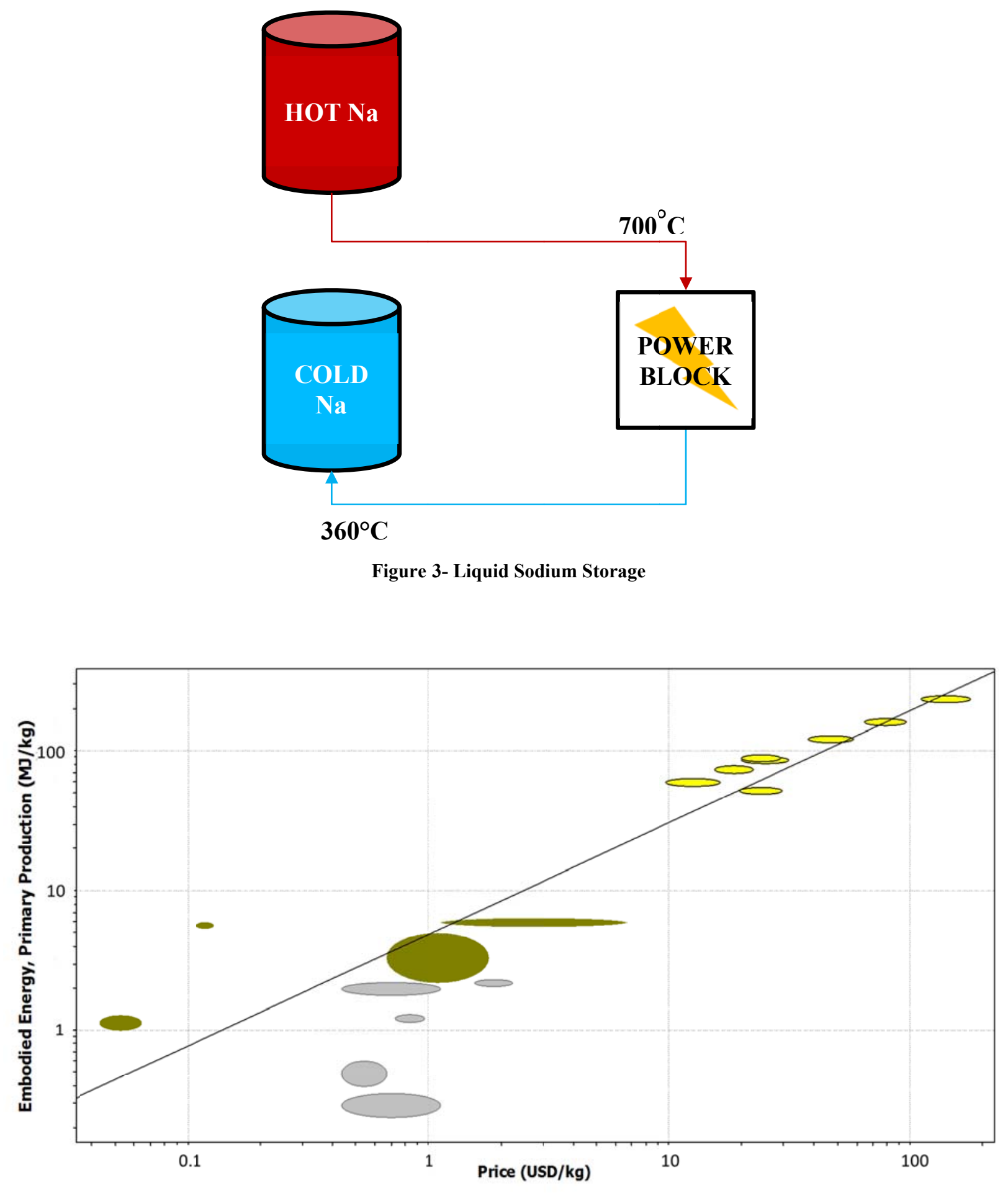

Figure 4- Embodied Energy vs. Price of Ceramics 


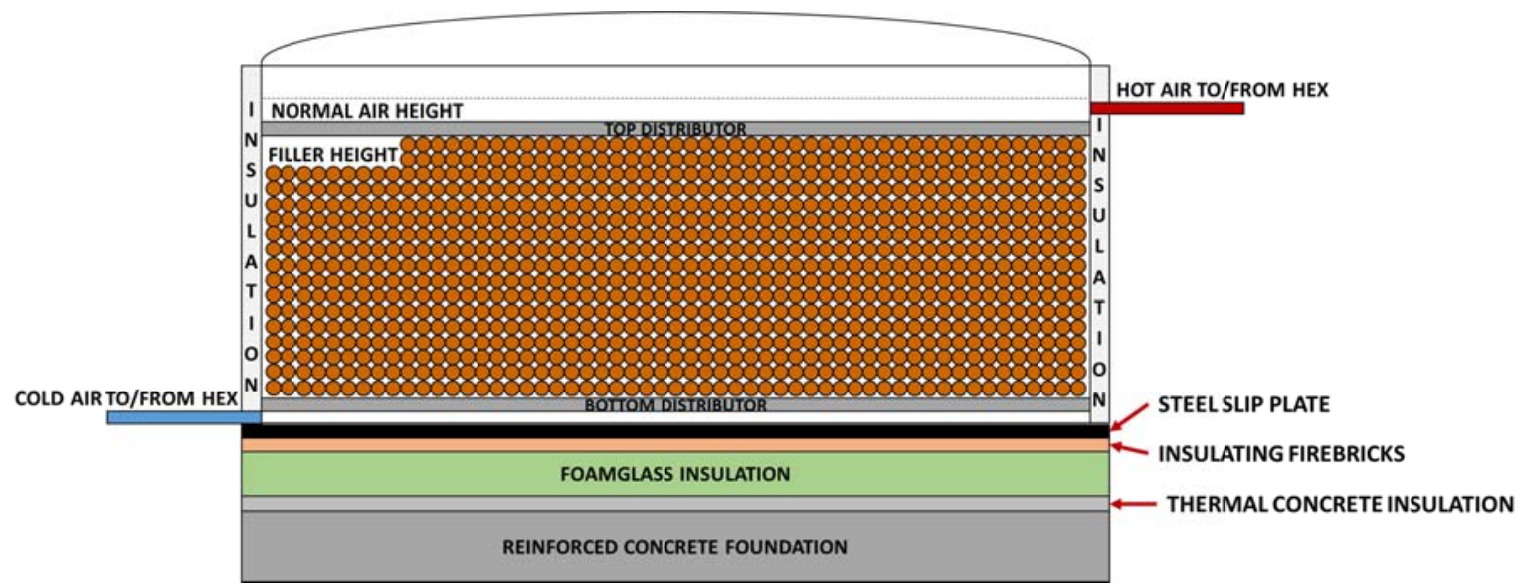

Figure 6- EPCM Tank Design

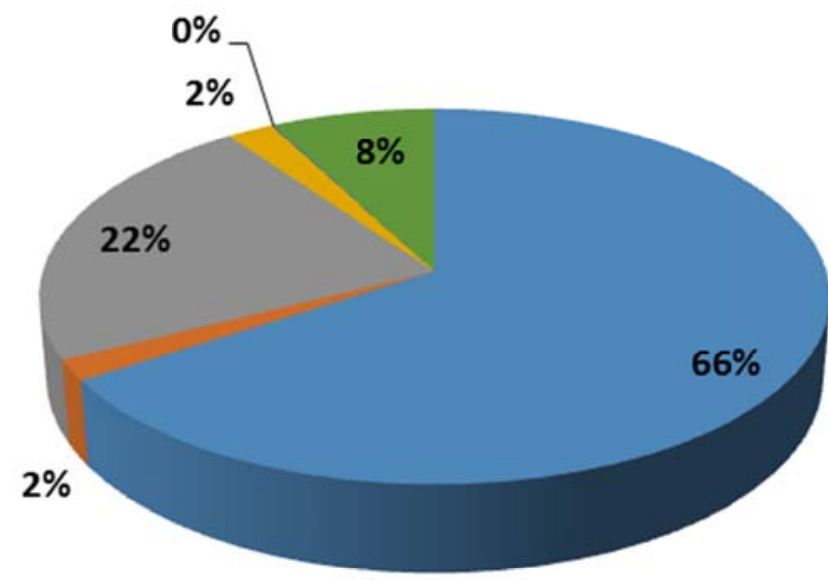

a Steel (Tank)

Concrete

n Insulation/Firebricks

PCM

- Geopolymer

Binder

\section{Total Embodied Energy= 19.3TJ}

Figure 5- Embodied Energy Breakdown of EPCM System 


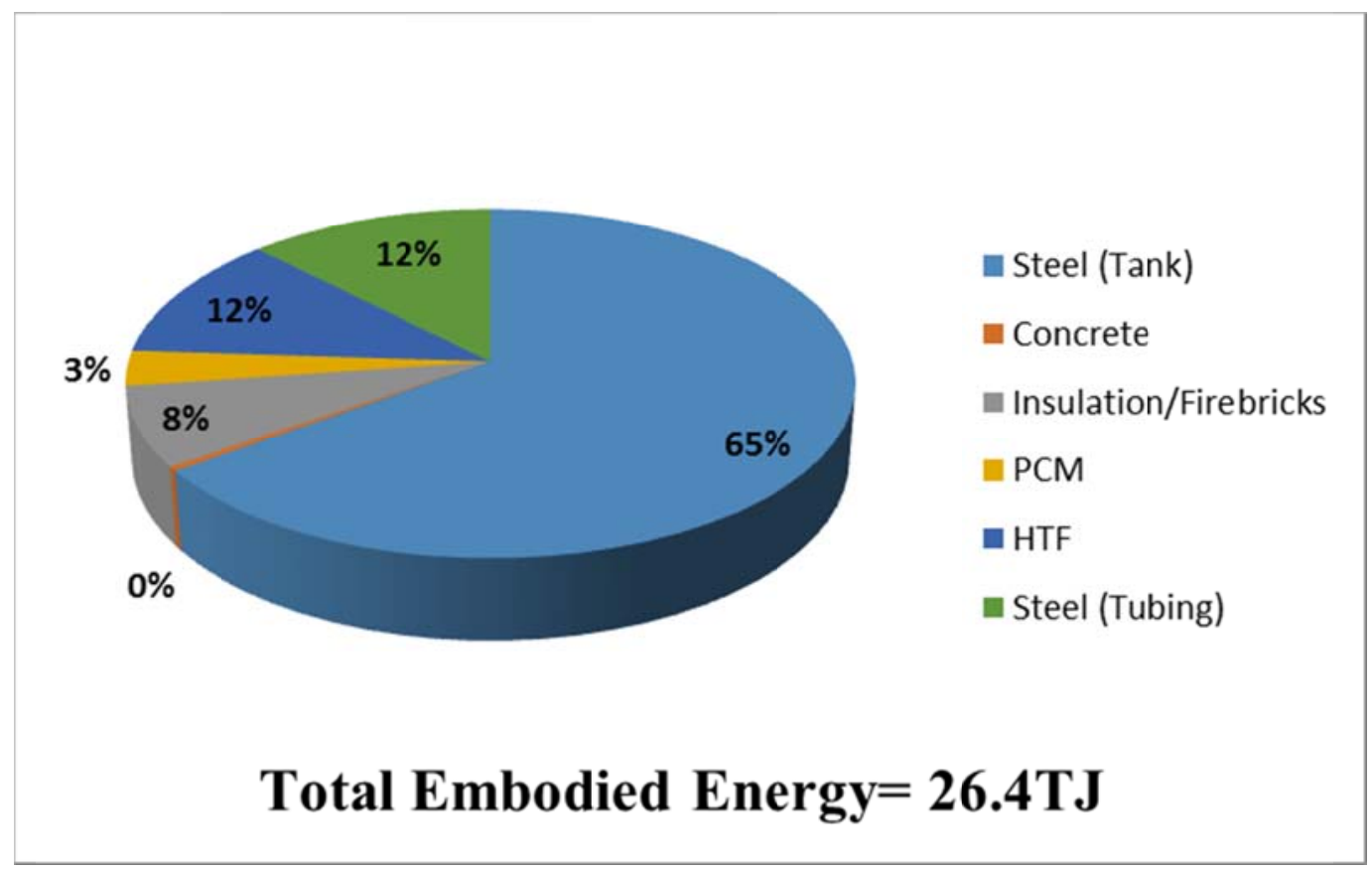

Figure 7- Embodied Energy Breakdown of Coil-in-Tank System

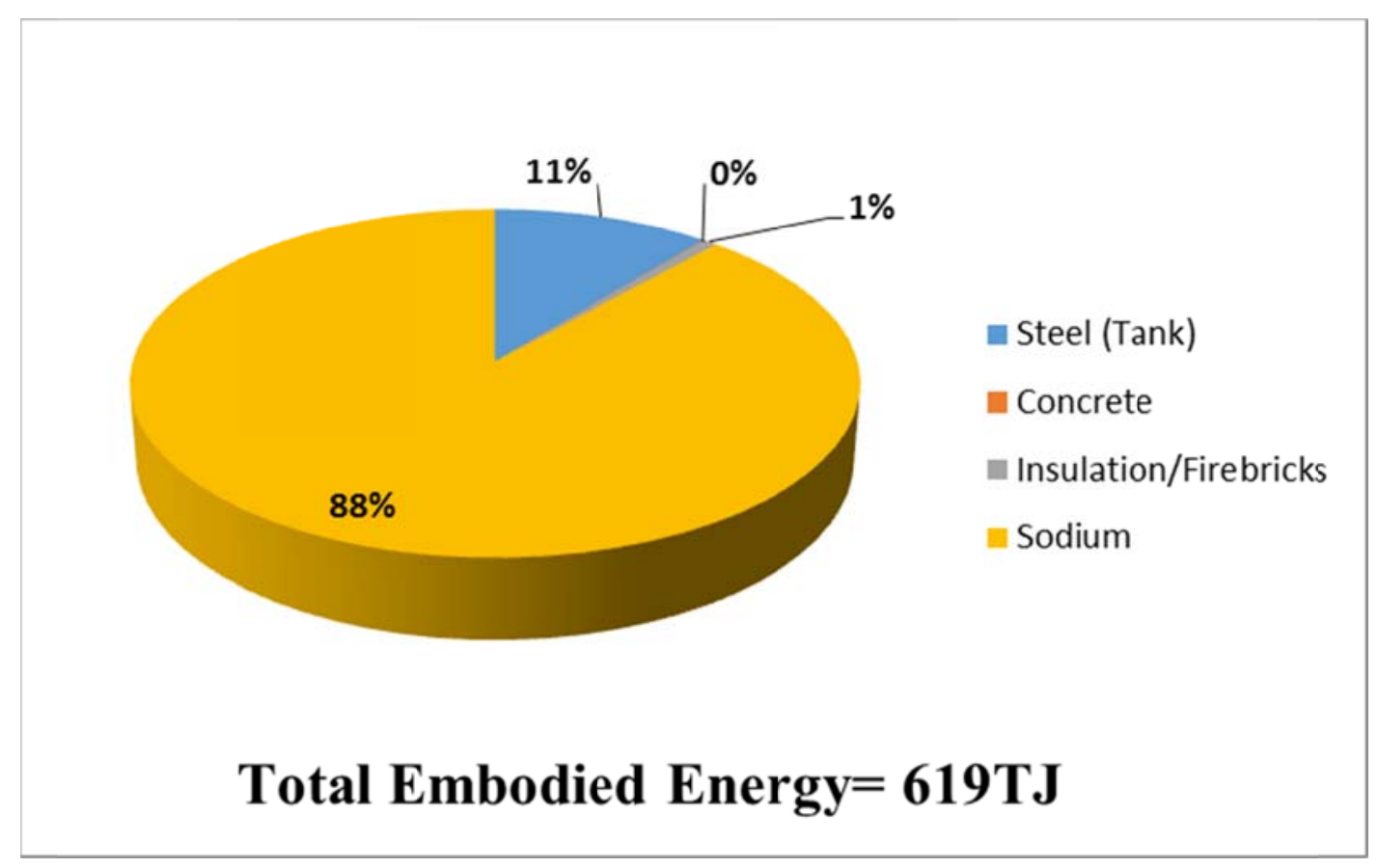

Figure 8- Embodied Energy Breakdown of a Two-Tank Sodium System 


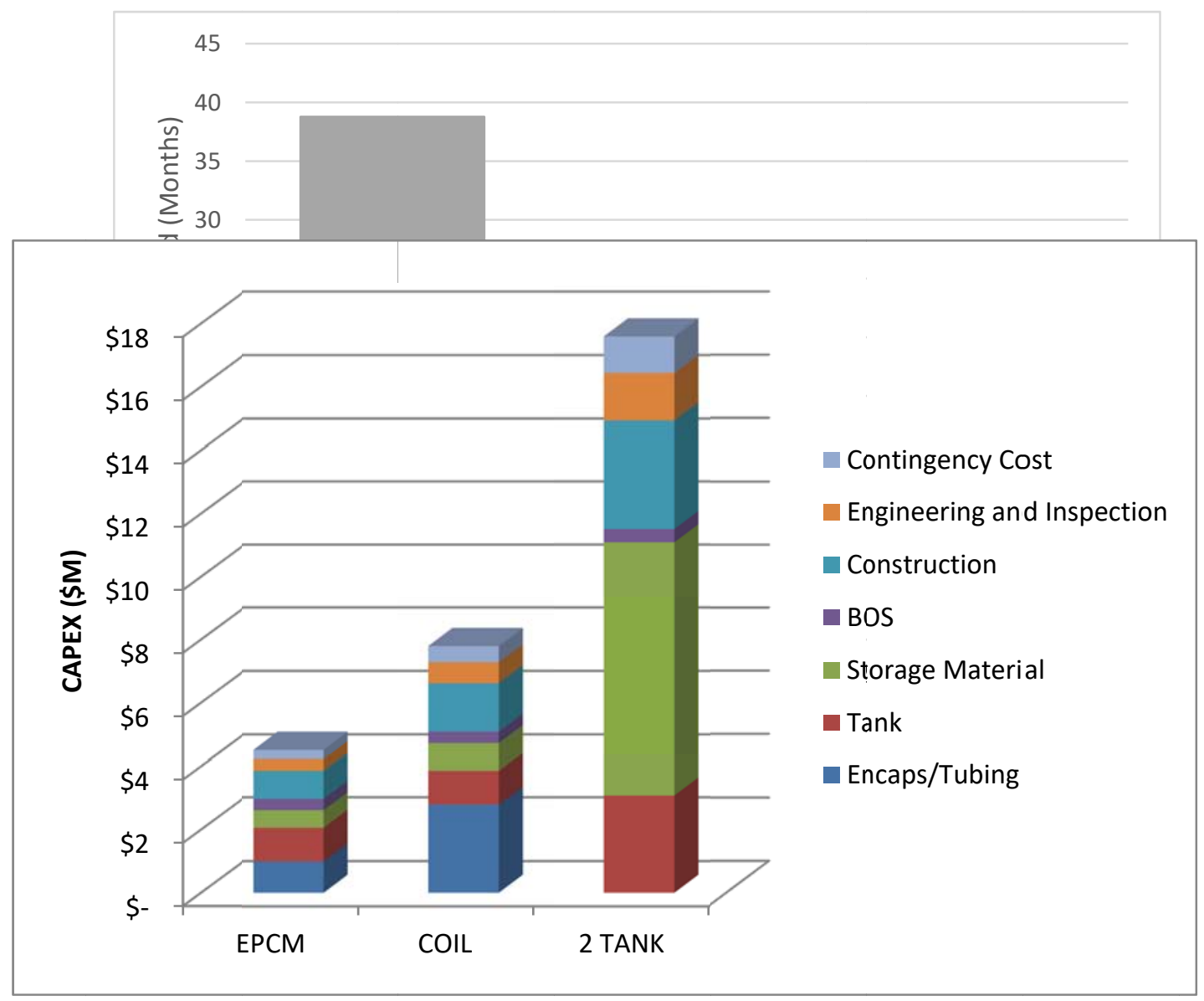

Figure 9- Cost Breakdown of Studied Systems

598

599

600

601

602

603

604 


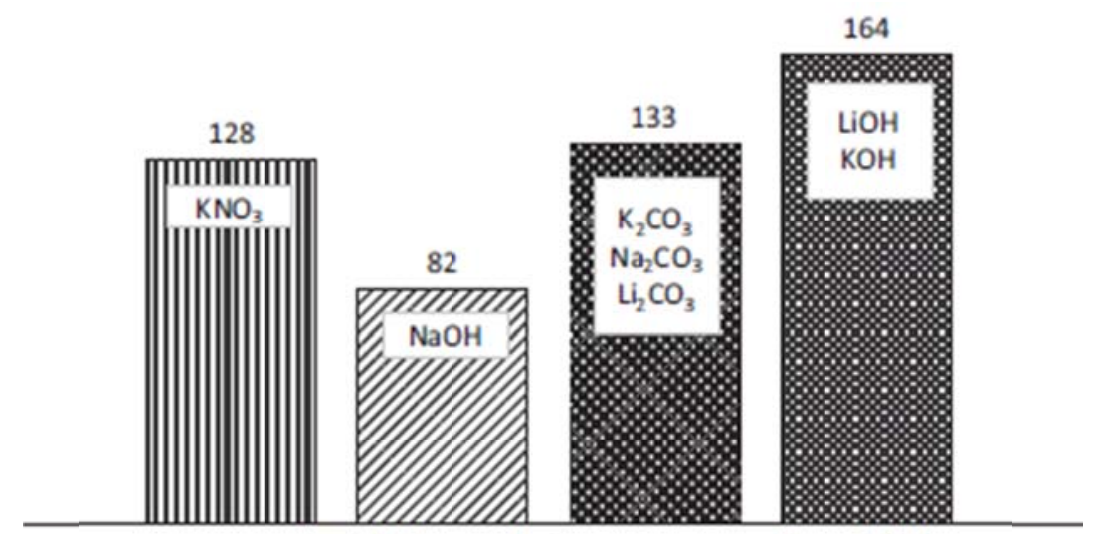

Total thermal storage energy, $\mathrm{E}_{\text {saved }}$ (GJ)

aCase 1 口Case 2 uCase 3 aCase 4

Figure 12- Storage Capabilities of Four PCM Systems

Adapted from [López-Sabirón et al, 2014]

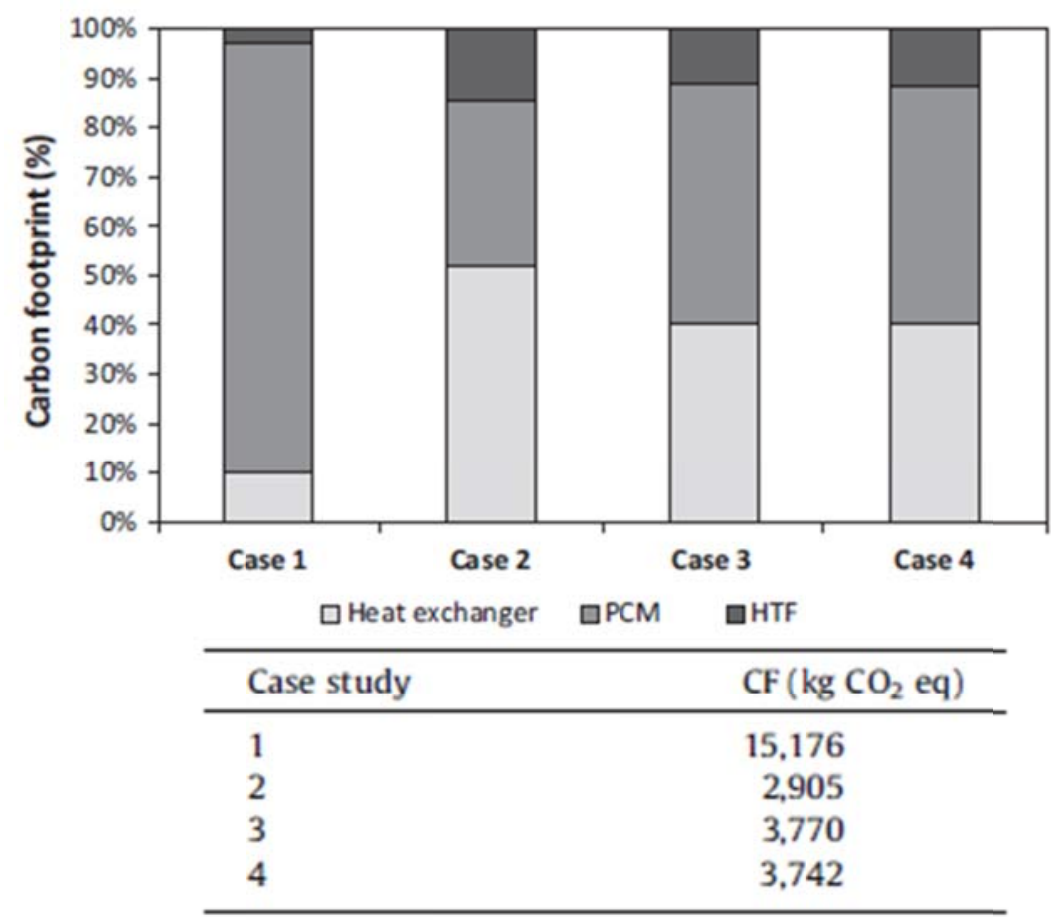

Figure 11- Carbon Footprint of Four PCM Systems

Adapted from [López-Sabirón et al, 2014]

605

606

607

608 


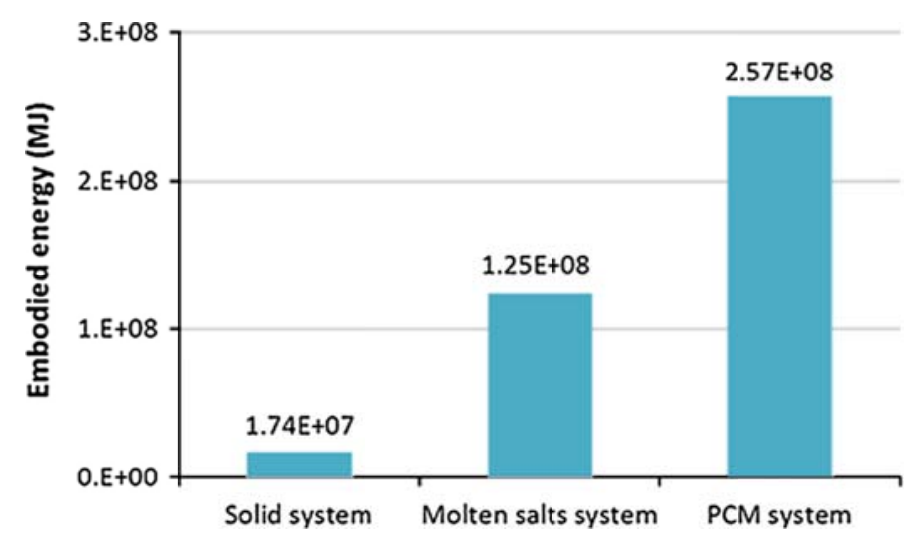

Figure 13- Embodied Energy of Solid, Liquid and PCM Systems

Adapted from [Miró et al, 2015]

609

610

611

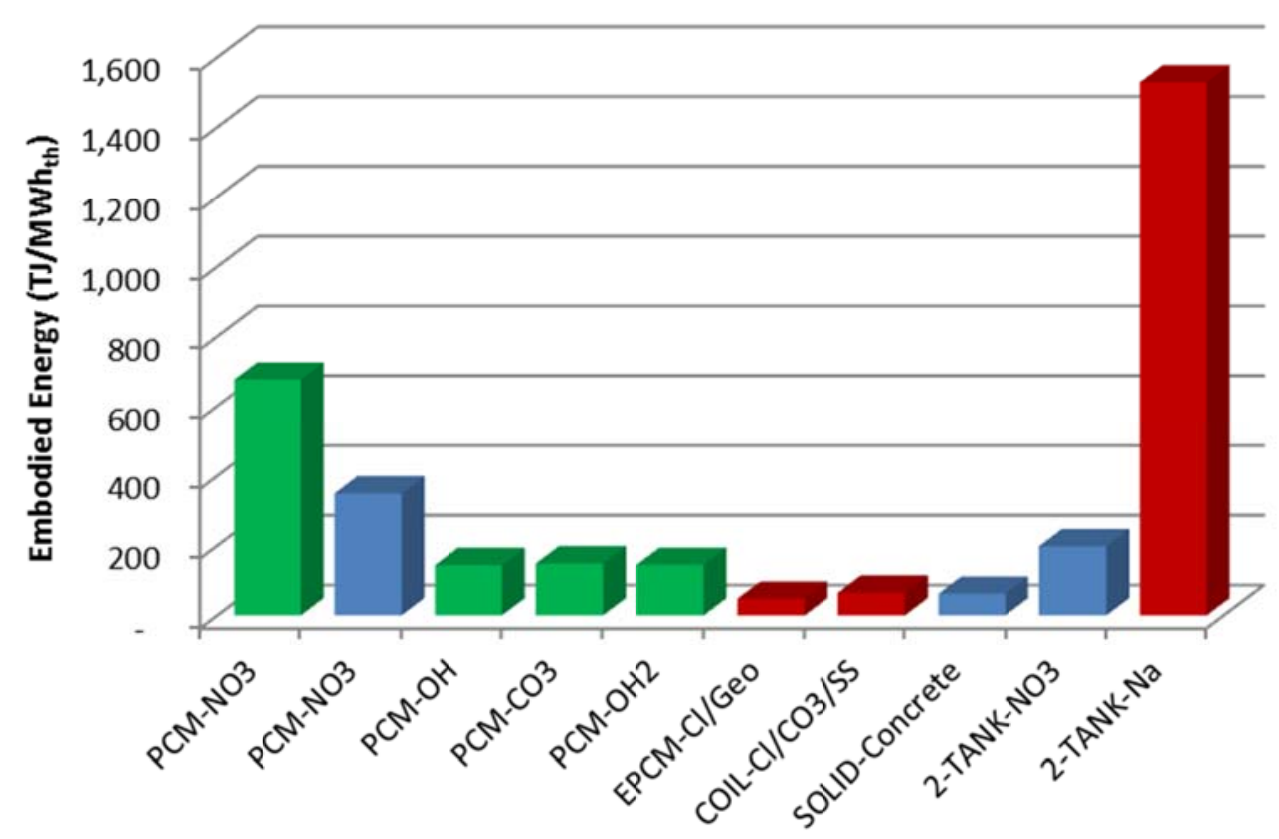

- LS et al, 2014

- Met al, 2015

- Current Study

Figure 14- Embodied Energy of Various Systems from Previous Studies

612 